\title{
VIP-Producing Neuroendocrine Tumor
}

National Cancer Institute

\section{Source}

National Cancer Institute. VIP-Producing Neuroendocrine Tumor. NCI Thesaurus. Code C26749.

An often clinically aggressive neuroendocrine tumor located in the pancreas or small intestine. It is composed of cells containing vasoactive intestinal peptide. It may cause intractable diarrhea and metabolic disturbances. 